\title{
캄보디아의 현대사와 개발원조의 흐름: \\ 일본, 미국, 중국의 ODA를 중심으로
}

손 성 일 (KOICA 이사장실 보좌관)

\section{목 차}

1. 서론

2. 캄보디아의 현대사

3. 캄보디아 수원의 시작

4. 주요 공여국의 ODA 특징

5. 캄보디아 ODA 전망

6. 결론

\section{1. 서론: 수원국의 역사적 맥락에서 ODA 이해하기}

공적개발원조(ODA, Official Development Assistance) 파트너십에 대한 논의가 국제사회 에서 폭넓게 진행되고 있다. 원조와 개발에 참여하는 주체들의 협력 강화가 핵심이다. 지난해 11월 개최된 제4차 부산개발원조총회에서도 '포괄적인 개발 파트너십 형성(Inclusive Development Partnership)' 이라는 공동원칙과 '남남협력 및 삼각협력에 대한 지원확대 (Broaden support for South-South and triangular co-operation)'라는 행동과제를 선 정함으로써 보다 광범위한 파트너십 강화에 대한 합의가 있었다.

수원국과의 개발파트너십은 $\mathrm{KOICA}$ 의 무상원조에도 주요한 정책적 가이드라인이다. 우리 정 부의 ODA 선진화계획의 일환으로 $\mathrm{KOICA}$ 는 '무상원조 선진화계획' 1)을 발표하였는데, 수원국 과의 정책협의를 바탕으로 한 국별협력전략(CPS, Country Partnership Strategy) 수립과 현 
지사무소의 권한과 기능을 강화한 현장 중심의 파트너십 확대를 중점 수행키로 했다. 이는 우리 $\mathrm{ODA}$ 의 한계 혹은 문제점으로 지적받아 온 '공여국 중심주의(Donor Centrism)' 2)의 탈피를 의미한다.

좋은 파트너십을 위해서는 상대에 대한 이해가 우선이다. 특히 개도국이라는 낮선 상대와의 파트너십을 기반으로 하는 원조사업에 있어서는 그 이해의 폭이 더 클 수밖에 없다. 이 경우 다 양한 정치·경제·사회·문화적 배경을 포괄하는 역사적 맥락에 대한 고려가 중요하다. 굳이 '역사란 과거와 현재의 끊임없는 대화이다' 라는 E. H. 카의 명제를 거론하지 않더라도, 어제의 일을 보아야 오늘의 현상을 정확히 이해하고 또한 오늘의 현상을 기초로 어제를 해석할 수 있음 은 주지의 사실이다. ODA도 마찬가지 맥락에서 접근이 가능하다.

수원국의 ODA 역사를 놓고 볼 때 많은 경우 보편성과 특수성이 동시에 발견된다. 이 글에 서 다룰 캄보디아를 비롯해 많은 수원국들은 대체로 국가재정이나 원조협의의 메커니즘에서 국 제사회에 의존적인 편이다. 원조에 익숙한 역사적 환경으로부터 기인한 수원국의 보편적 특징 이다. 하지만 그 보편성은 개별 국가마다의 역사적 배경과 그 진로에 따라 다양한 현상으로 전 개된다. 한 국가의 원조역사가 갖는 특수성이 중요한 까닭이다.

개발파트너십 강화를 위해 굴곡 많은 현대사의 아픔을 지닌 캄보디아의 원조역사를 살펴보 는 것은 수원국의 $\mathrm{ODA}$ 특수성을 이해하는 좋은 사례가 될 것이다. 이 글은 캄보디아가 가진 특 수한 현대사적 흐름과 그것이 가져온 대 캄보디아 개발원조의 역사를 1990년대 이후를 중심으 로 살펴보고자 한다. 그 과정에서 일본, 미국, 중국으로 대표되는 주요 공여국의 원조의 내용과 특징을 구체적으로 다룰 예정이다. ${ }^{3)}$ 이를 통해 캄보디아 원조를 시행하고 있는 KOICA와 유관 정부부처 및 민간 - 시민사회 등이 캄보디아 원조의 역사적 배경에 대한 이해를 바탕으로 개발 파트너십에 기초가 되는 유의미한 정보를 확인할 수 있을 것으로 기대한다.

1) 2010.2월 수립된 'KOICA 선진화 계획(2010-2015)' 은 글로벌 ODA 전문기관으로의 도약을 위한 KOICA의 로드 맵을 제시한 것으로, 사업수행시스템 선진화방안 및 조직인프라 확대개편방안 등을 담고 있다.

2) 참여연대에서 개설한 시민강좌 〈한국 ODA의 길을 묻는다〉 제1회 '국제사회가 말하는 ODA의 허와 실(2011.9.8)' 에서는 ODA 정책과 의사결정 방식이 수원국의 현지여건과 필요, 지속가능성을 담보하지 못한 체 한국형 컨텐츠 를 제공하는데 급급함을 비판하고 있다.

3) 그간의 대 캄보디아 지원규모와 현재의 ODA 영향력, 국가의 캄보디아 현대사와의 관계와 정치· 경제적 이해관계 등을 고려해 상기 3 개국을 분석대상으로 선정했다. 


\section{2. 캄보디아의 현대사}

동남아시아의 작은 나라 캄보디아는 사실 이미 8세기부터 앙코르왕국이라는 고대국가의 체 제를 갖추며 독립국가로 성장했다. 16 세기 이후부터는 태국과 베트남 그리고 프랑스의 지배를 차례로 받기도 했지만 크메르 민족으로서의 명맥은 유지가 되었다. 특히 현대까지 내려오는 앙 코르왕국 시대의 문화유산은 캄보디아의 정신이고 국민들의 자부심이다. 아쉽게도 오랜 외세의 지배로 인해 근대국가로의 성장과 이행과정은 더뎠으며, 식민 지배를 경험했던 보통의 개도국 처럼 정치 · 경제적 기반이 취약한 가운데 신생 독립국가로 탄생했다.

1953년 프랑스로부터 독립한 캄보디아는 기존의 왕정 체제를 강화하여 국민을 통합하고 국 가 재건의 기반을 만들어간다. 1960년대는 캄보디아 역사상 가장 행복한 나날이었다. 독립 후 주변국의 침입도 없었고 20 만톤 이상의 쌀도 수출할 정도로 경제적으로도 풍요로운 시기를 맞 았다. ${ }^{4)}$

하지만 곧 베트남전쟁의 불똥이 튀면서 현대사의 암흑기가 시작된다. 베트남과의 교착상태 를 타개하려는 미국이 1969년 중립주의를 표방하던 캄보디아를 공격하게 되고 이 과정에서 론 놀(Lon Nol) 장군이 이그는 친미정부가 쿠데타를 통해 1970년 권력을 잡게 되었다. 민심과 동 떨어진 일련의 상황은 폴폿(Pol Pot)이라는 크메르루즈(Khmer Rouge) 반군지도자의 출현을 불러왔으며 이들 게릴라부대는 농촌지역을 기반으로 반미 · 반정부 저항활동을 펼치며 세력을 확장했다.

1975년 베트남전 종결과 함께 결국 캄보디아의 정권도 교체가 된다. 친미정권을 무력으로 진압한 폴폿은 민주캄푸치아라는 국가를 수립한다. 민주캄푸치아의 이념은 고대 앙코르왕조 시 대로의 복귀와 원시공산사회의 구성이었다. 극단적 공산주의가 왜곡된 크메르 민족주의와 억압 적 정치체제와 결합하면서 이 시대는 캄보디아 현대사의 암흑기가 되었다. 이후 1979년 베트남 군을 등에 업은 훈센(Hun Sen)을 비롯한 친베트남 세력이 폴폿 정권을 축출하고 새로운 정부

4) 이러한 성장에 힘입어 캄보디아는 1966년 제2회 신생국올림픽(Games of the New Emerging Forces)을 개최 하였다. 당시 대회의 규모가 어느 수준이었는지는 알려지지 않고 있으나 무려 40년 전에 이와 같은 국제대회를 치렀다는 것은 당시의 캄보디아 국력을 알 수 있는 중요한 대목이다. (캄보디아 선교센터,

http://www.cmic21.org)

5) 크메르루즈의 자국민 대량학살과 반인도적 범죄에 대한 국제전범재판은 유엔과 국제사회의 도움을 받아 2007년 처음 개최되었다. 1 기 재판에서는 악명 높았던 정치범수용소(Toul Slang)의 당시 교도소장에게 종신형을 선고한 바 있으며(2012.2월), 현재는 크메르루즈 외교장관을 포함한 핵심 권력인사 4명에 대한 2기 재판이 진행되고 있

다. 정권의 최종 책임자였던 폴폿은 1998년 반군 근거지에서 시체로 발견되었다. 
를 구성하게 되면서 짧지만 혹독했던 민주캄푸치아 시기는 종말을 고하게 된다.

4년간 집권했던 크메르루즈의 만행은 이미 국내에도 많이 알려져 있다. 과거 정부의 관료들 과 지식인들을 포함한 일반 대중에 대한 무자비한 숙청과 유배, 교육·종교·문화·경제 등 사 회 전 영역의 파괴, 집단농장 운영을 통한 원시공산체제 구성 등 무자비하고 퇴행적인 국가 운 영으로 사회는 한 순간에 거대한 감옥으로 바뀌었다. 이 시기에 무려 200만 명이 처형되거나 질 병과 영양실조로 목숨을 잃었다는 통계만 보더라도 '킬링필드(Killing Field)' 로 상징되는 캄보 디아 현대사의 가장 처참한 단면을 엿볼 수 있다. 한 세대가 지난 2000년대 후반 들어와서야 '역사 바로세우기' 작업이 진행되고 있다.5)

크메르루즈 시기가 가져온 역사의 후퇴는 사회 곳곳에 무거운 트라우마를 남겼다. 모든 인 적자원의 단절, 마을공동체의 해체, 산업의 파괴와 불균형, 계속되는 정파 간의 갈등과 부정부 패의 만연 등 산재한 문제는 어느 것 하나 쉽게 해결될 수 없었다. 엎친 데 덮친 격으로 1980년 대에도 미국, 중국, 소련 등 강대국과 베트남, 태국 등 주변국들의 이해와 후방지원이 얽힌 내전 으로 인한 정국 혼란이 계속되었다. 이러한 문제는 1991년 파리평화협정이 체결되면서 비로소 해결의 실마리를 마련할 수 있었다. 즉, 파리평화협정과 함께 국제사회의 본격적인 개발원조가 시작되면서 캄보디아는 과거의 상처로부터 벗어나는 성장 동력을 갖추게 된 것이다.

\section{3. 캄보디아 수원의 시작}

\section{(1) 파리평화협정과 재건복구위원회}

크메르루즈 게릴라군에 의해 계속된 내전은 마침내 1991년 10월 UN 주도의 파리평화협정6) 의 체결과 함께 종식되었다. 물론 그 후에도 정파 간 갈등과 무력충돌이 있긴 했으나 파리평화 협정을 통해 비로소 캄보디아가 국제사회로부터 적법하고 정통성을 지닌 국가로 인정받게 되었 다. 파리평화협정을 기점으로 국제사회의 재건지원과 인도적 원조가 본격적으로 시작되었다는 점에서도 1991년이 의미가 있다.

파리평화협정 이전에도 캄보디아에 대한 원조는 있었다. 1979년 폴폿 정권이 무너지면서 소

6) 파리평화협정(Agreement on a Comprehensive Political Settlement of Cambodia Conflict)은 프랑스와 인 도네시아가 공동 주최하고 캄보디아의 4 개 정파, 안보리 5 개 상임이사국(미국, 영국, 프랑스, 소련, 중국), ASEAN 6 개국(브루나이, 인도네시아, 필리핀, 태국, 말레이시아, 싱가포르), 베트남, 라오스, 일본, 호주, 캐나다, 인도, 유고 등 19 개국이 참가하였다. (크메르의 세계, http://cafe.daum.net/khmer-nomad) 
련을 중심으로 한 동유럽 공산권 국가들의 양자원조가 주를 이루었으며, 크메르루즈 몰락에 핵 심역할을 했던 베트남도 공여국의 역할을 담당했다. 서방국가들은 직접적인 원조보다는 $\mathrm{UNICEF}, \mathrm{FAO}, \mathrm{UNWFP}$ 등의 국제기구를 통한 다자원조에 집중했다. OXFAM, CARE, World Vision 등의 국제 $\mathrm{NGO}$ 들이 등장한 것도 이 시기다. ${ }^{7)}$

1991년 10월 23일, 캄보디아 4개 정파의 휴전, 난민귀환, 무장해제, 군대해산, 자유총선 등 의 전권 위임에 합의하는 파리평화협정이 체결된다. 이로서 캄보디아는 ' $\mathrm{UN}$ 캄보디아 과도행 정기구(UNTAC, United Nations Transitional Authority in Cambodia)'의 임시 관리 하 에 놓이게 되었다. UN은 이후 1993년 9월까지 약 16 억불을 지출하며 UN평화유지군과 민간 인사를 파견한다. 그리고 1993년의 총선거와 함께 마침내 캄보디아는 현재의 캄보디아왕국 (Kingdom of Cambodia)으로 탄생하게 되었다.

파리평화협정 결정에 따라 1992년 6월 국제기구 대표들이 동경에 모인다. 그리고 일본과 UNDP를 공동의장으로 하는 '캄보디아재건각료회의(MCRRC, Ministerial Conference on the Rehabilitation and Reconstruction of Cambodia)'를 개최한다. 이 자리에서 참가국들 은 캄보디아 재건과 복구에 관한 선언과 평화이행에 관한 선언을 채택하며 재건기금으로 8 억8 천만불을 조성하는데 합의했다. 그리고 '캄보디아재건복구위원회(ICORC, International Committee on the Reconstruction and Rehabilitation of Cambodia)'라는 더욱 지속적 인 협력 기구를 세우기로 결정한다. 이는 UNTAC의 위임종료 후에도 원조의 연속성을 추구하 기 위한 목적이 크다.

ICORC 설립을 계기로 캄보디아에 대한 국제사회의 원조가 체계적이고 대규모로 확대되기 시작했다. 1993년 9월부터 1995년 3월까지 3차례에 걸쳐 개최된 ICORC 회의에서는 모두 22 억9천만불의 원조가 공약되었고 33 개국 12 개 국제기구에서 참여하였다. ICORC 회의는 원조액 수도 클 뿐만 아니라 원조정책에 대한 가이드라인까지 마련하면서 초보 수원국 캄보디아의 역 량개발을 지원했으며, 특히 긴급 재건지원에 초점을 맞춰 전후 복구의 성장토대를 마련했다는 의미가 있다. ${ }^{8)}$

7) 국제사회의 원조는 1979년부터 1980년대 초까지 집중된다. 소련은 2억8천만루블의 무상원조를 지원했고 베트남 은 1억2천만불, $\mathrm{UNN}$ 기구와 적십자사 등 국제NGO는 6억3천만불 규모를 긴급구호와 인도적 지원을 위해 지원했다. 이후 사회주의를 표방하는 베트남 세력을 몰아내기 위해 서방국가들은 1980년대 중반부터 본격적으로 원조금지 정책을 펼쳤고, 이를 계기로 캄보디아에 대한 원조는 크게 줄어드는 추세를 보인다. (미국의회도서관, http://memory.loc.gov/frd/cs/khtoc.html)

8) 세 차례의 ICORC 회의는 파리와 동경을 오가며 개최되었고 이후 CG 회의도 파리와 동경이 순차 개최했다. 캄보 디아 원조 초창기 프랑스와 일본의 영향력과 관심을 확인할 수 있는 대목이다. 


\section{(2) 원조공여국회의와 개발협력포럼}

파리평화협정의 산물이었던 캄보디아재건복구위원회가 1995년 활동을 종료하면서 이를 대 체하는 '캄보디아원조공여국회의(CG, Consultative Group for Cambodia)' 가 1996년 7월 동경에서 열린다. 기존의 원조활동이 공여국 주도의 긴급재건복구 중심이었다면 새롭게 구성된 $\mathrm{CG}$ 회의는 수원국과 공여국의 파트너십에 기초한 협력체계를 본격화 하였다. CG 회의는 약 2 년에 한 번씩 총 8회에 걸쳐 개최되면서 원조공여국과 캄보디아 정부의 개발 아젠다 선정과 원 조실무를 주도하게 된다.

초창기 CG 회의는 World Bank가 주최하고 미국, 일본, 영국 등 주요 공여국과 $\mathrm{ADB}, \mathrm{IMF}$ 등 국제금융기관이 참여하는 구도로 시작되었다. 이후 현 훈센총리 집권의 계기가 되는 1998 년 총선거를 거치며 캄보디아 정부도 원조회의에서 주요 당사국으로 참여하게 된다. 이로써 수원 국의 참여가 보장되는 실효적인 원조회의가 구성될 수 있었다. 그리고 2002년 개최된 제6차 $\mathrm{CG}$ 회의부터는 캄보디아 정부와 World Bank가 공동 의장을 맡게 되면서 형식상 수원국과 공 여국이 공동의 의사결정을 기반으로 한 회의 운영이 가능케 된다.

이처럼 캄보디아 정부가 원조회의의 전면에 부상할 수 있었던 것은 정권의 지속적인 경제성 장과 안정적인 국가운영의 결과로 볼 수 있다. 1998년 출범한 훈센정부는 이후 연 평균 $9 \%$ 이 상의 경제성장률을 보이는 한편 실타래처럼 얽힌 정파와 계파 간 갈등과 내전의 상흔을 비교적 원만히 수습하는 지도력을 보이면서 국민들의 지지를 얻게 되었다. 캄보디아 정부의 안정적 성 장과 개혁을 효과적인 원조수행의 지렛대로 삼으려는 원조공여국 입장에서도 이는 의미 있는 진전이었다. 수원국의 주인의식(ownership)과 현지 주도(local stewardship)를 점점 강조하 게 된 국제원조사회의 동향과도 맥을 같이 한 필수적 변화이기도 했다. 제6차 CG 회의부터는 캄보디아의 수도 프놈펜이 개최지가 된 것은 그런 점에서 매우 상징적이고 혁신적인 사례라 할 수 있다.

1996년부터 2006년까지 CG 회의를 통해 서약된 원조규모는 총 38억5천만불에 달한다. 경 제개발과 사회인프라 구축, 행정개혁 등이 주요 이슈였던 1990년대를 지나 2000년대 들어서는 $\mathrm{UN}$ 의 새천년개발목표(MDGs), 빈곤감축, 사회안전망 확보 등 국제사회의 주요 개발협력 논의 가 수용되기 시작했다. 그 과정에서 국제 개발 $\mathrm{NGO}$ 와 캄보디아의 개발 $\mathrm{NGO}$ 도 CG 회의에 참여 하는 진전이 있기도 했다. 요약하자면 이 시기에는 포괄적이고 구속력 있는 국제사회의 원조정 책과 캄보디아 정부의 개발전략이 유기적인 결합을 이루면서 상호 파트너십을 기반으로 한 원 
조성과를 거둘 수 있었다.

캄보디아개발협력포럼(CDCF, Cambodia Development Cooperation Forum)'은 캄보디 아 정부가 본격적으로 주도하는 첫 번째 원조회의라 할 수 있다. 2007년 6월 프놈펜에서 개최 된 제1회 $\mathrm{CDCF}$ 포럼은 정부가 마련한 '국가전략개발계획(NSDP, National Strategic Development Plan 2006-2010)' 의 도입을 확인하는 한편 공여국과 정부의 NSDP 달성 노력 을 명시화함으로써 정부가 주도하고 공여국의 원조가 지원하는 국가개발의 협력체계를 구축할 수 있었다. 이 회의에서 캄보디아는 6.9 억불에 달하는 원조자금 지원을 약속받기도 했다. 공여 국의 원조를 개발 매커니즘의 일부로 끌어들이겠다는 캄보디아 정부의 강한 의지가 실현되었다 는 점에서 신생 원조회의의 출범이 의미가 있다.

2008년 12 월의 제 2 회 $\mathrm{CDCF}$ 포럼에서는 그해 재집권에 성공한 훈센정부의 국정 청사진인 '사각화전략 II(Rectangular StrategyII)' 의 실행과 세계적 금융위기에 따른 정부의 주요 개 혁과제를 다루었다. 이 자리에서 공여국은 9.5 억불의 원조를 서약함으로써 원조의 지속적인 확 대 흐름을 계속 이어간다. 2010년 6월 개최된 제3회 포럼에서는 보완된 'NSDP(2009-2013)' 의 달성 과제와 지속가능한 성장을 위한 토대마련 방안을 협의하였다. 특히 제 3 회 포럼에서는 국제사회의 원조자금이 전 세계적으로 축소 · 동결되는 여건에도 불구하고 전년도 10 억불보다 $10 \%$ 상승한 11 억불의 캄보디아 ODA 지원을 발표했는데, 이는 세계경제 위기 상황 속에서 최빈 국인 캄보디아에 대한 지원 필요성이 확대된 측면도 있지만 동시에 캄보디아 정부의 수원 여건 이 그만큼 개선되고 원조효과성 향상을 위한 장치가 원활히 작동된 결과로 해석할 수 있다.9) 이 상에서 살펴본 캄보디아 수원의 역사적 단계와 경제성장률 및 $\mathrm{ODA}$ 의 흐름을 정리하면 아래 표 와 같다.

9) 캄보디아 원조통계가 작성되기 시작한 1992년부터 2010년까지 총 캄보디아 원조액수는 약 109억불로, 이는 그간 원조공여국이 원조회의 시 서약한 총액 96.1 억불보다 많은 액수이다. 이는 원조회의에 참여하지 않는 중국과 같은 국가에서 별도의 원조서약 없이 개별 집행한 결과로 해석된다. 연도별 원조집행액은 아래와 같다.

10) 2009년의 캄보디아 GNI 대비 순원조액 비율은 7.5\%로 2000년에 비해 $3.7 \%$ 하락했다. 같은 기간에 라오스는 $7.2 \%$, 베트남 4.2\%, 인도네시아 0.2\%, 필리핀 0.2\%를 기록하였다. (OECD, http://www.aidflows.org)

\begin{tabular}{|c|c|c|c|c|c|c|c|c|c|c|c|c|c|c|c|c|c|c|c|}
\hline 구분 & 92 & 93 & 94 & 95 & 96 & 97 & 98 & 99 & 00 & 01 & 02 & 03 & 04 & 05 & 06 & 07 & 08 & 09 & 10 \\
\hline 지원 & 2.5 & 3.2 & 3.6 & 5.1 & 5.2 & 3.8 & 4.3 & 4.0 & 4.7 & 4.7 & 5.3 & 5.4 & 5.6 & 6.1 & 7.1 & 7.8 & 9.8 & 10.0 & 10.7 \\
\hline
\end{tabular}

(출처 : The Cambodia Development Effectiveness Report 2011) 


\section{〈표 : 캄보디아 수원역사와 연도별 경제성장률 및 ODA 흐름〉}

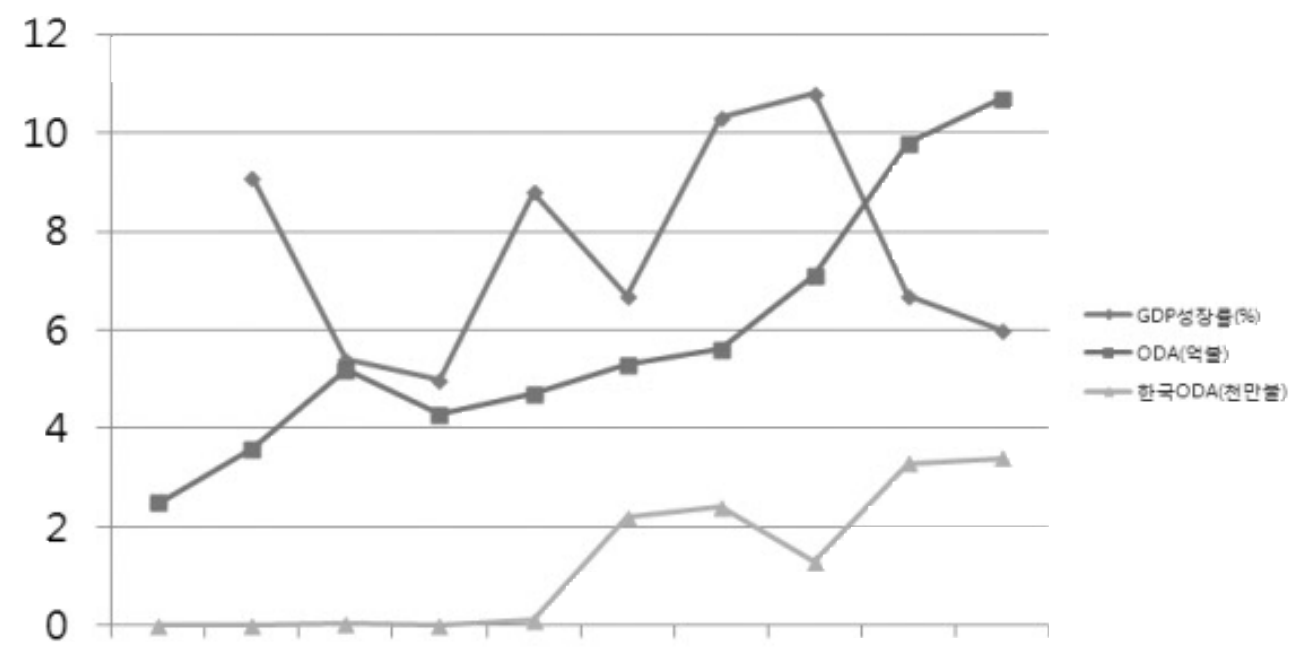

1992199419961998200020022004200620082010

1991넌

파리평화협정

재건의 기들 마련
1993넌

재건복구위원회

개발원조의 태동
1996넌

원조공여국회의

경제성장과 안정
2007년

개발헙력포럼

주인의식의 확립

(자료: 세계은행, 원조효과성보고서 참고하여 재구성)

\section{4. 주요 공여국의 ODA 특징}

\section{(1) 현대사를 통해 본 ODA 특징}

앞서 살펴본 바와 같이 캄보디아의 ODA는 1980년대부터 시작되어 1991년 파리평화협정을 계기로 본격화하고 2000년대 들어서며 공여국과 수원국의 파트너십을 기반으로 한 체계적인 원조로 정착되는 과정을 거친다. 원조공여국의 개별 ODA 흐름도 큰 틀에서는 이러한 경향을 반영한다고 할 수 있다. 일본, 미국, 중국 등 핵심 공여국의 ODA 특징을 살펴보기에 앞서 캄보 디아의 전반적인 $\mathrm{ODA}$ 특징을 현대사적 관점에서 우선 개괄한다면 아래와 같다.

첫째, 크메르루즈라는 역사적 시련에 어떻게 연관되었느냐에 따라 각국의 원조 경향성에 차 이가 나타난다. 미국의 경우 베트남전쟁 과정에서 캄보디아에 막대한 피해를 입혔다는 점 외에 
도 친미정부 수립에 대한 반감으로 인해 폴폿 정권이 등장하는 결정적 빌미를 제공했다는 점에 서 캄보디아의 우방으로서의 원조제공자가 될 수 있는 상황은 아니었다. 중국은 크메르루즈의 극단적 공산주의 노선에 대해 동의와 지지를 보냈다는 점에서 이후 출범한 정부와의 유대관계 가 우호적일 수만은 없었다. 베트남은 반크메르루즈 세력을 후원하고 1980년대 캄보디아를 실 제적으로 지배하는 과정에서 전후 원조활동에 적극적이었다.

둘째, 여느 개도국과 마찬가지로 식민지배 경험의 연결고리가 ODA 지원에도 영향을 미쳤 다. 프랑스는 19 세기와 20 세기에 걸쳐 약 100 여 년 동안 캄보디아를 식민지화했던 원죄가 있고 일본도 2 차 대전 기간에 캄보디아를 대동아공영권으로 확장시키려는 갈등이 있었다. 이러한 역 사적 배경이 이유였는지 프랑스와 일본은 파리평화협정 이후 본격적인 원조의 시대를 맞아 대 표 공여국으로 활발히 활동하게 된다. 특히 일본은 프랑스와 달리 원조 규모에 있어서도 압도적 인 지원을 아끼지 않음으로써 캄보디아 사회 안정 이후에도 원조 영향력을 계속 가져갈 수 있었 다.

셋째, 현대사가 비극이 몰고 온 국가성장 동력의 상실은 ODA에 전적으로 의존할 수밖에 없 는 사회구조를 고착화했다. 크메르루즈 몰락 이후 베트남과 소련, 서방국가들로부터 지원된 $\mathrm{ODA}$ 가 전후 복구의 주요 재정으로 활용되었고, 1990년대 원조공여국회의를 통해 연평균 4억 불 이상의 원조가 집중되면서 부족한 국가재정을 대체할 수 있었다. 2000년대 이후 캄보디아의 GNI 대비 순수원조액 비율은 $11 \%$ 대에서 $7 \%$ 대로 점차 줄어드는 추세이긴 하나 동남아 인근국 가에 비해 매우 높은 수준의 ODA 의존도를 보이고 있다. 10) 2011년 캄보디아 정부예산이 약 24 억불 편성되었는데, 그해 공여국의 원조서약규모가 11 억불에 육박한다는 점을 고려하면 정부운 영에서 ODA가 차지하는 규모가 여전히 상당하다는 것을 알 수 있다.

마지막으로, $\mathrm{ODA}$ 메커니즘이 공여국 중심에서 수원국 중심으로 이동 했다. 초기 캄보디아 에 대한 원조논의는 공여국이 주도했다. 이후 2000년대 들어 공여국과 수원국의 공동 참여와 협의 형식의 원조집행체제가 마련되었고, 2007 년 $\mathrm{CDCF}$ 포럼부터는 국가개발의 큰 틀에서 원 조를 어떻게 활용하고 효율화시킬 것인지를 캄보디아 정부가 주도하게 된다. 원조의 형식과 내 용이 수원국의 오너십을 강조하는 방향으로 점차적으로 바뀌어 왔음을 알 수 있다. 이런 변화의 핵심 요인은 안정적인 국가 운영과 경제성장을 기반으로 한 정부 거버넌스의 향상이라 할 수 있

10) 2009년의 캄보디아 GNI 대비 순원조액 비율은 $7.5 \%$ 로 2000 년에 비해 $3.7 \%$ 하락했다. 같은 기간에 라오스는 $7.2 \%$, 베트남 $4.2 \%$, 인도네시아 0.2\%, 필리핀 0.2\%를 기록하였다. (OECD, http://www.aidflows.org)

〈단위 : 억불〉

\begin{tabular}{|c|c|c|c|c|c|c|c|c|c|c|c|c|c|c|c|c|c|c|c|}
\hline 구분 & 92 & 93 & 94 & 95 & 96 & 97 & 98 & 99 & 00 & 01 & 02 & 03 & 04 & 05 & 06 & 07 & 08 & 09 & 10 \\
\hline 지원 & 2.5 & 3.2 & 3.6 & 5.1 & 5.2 & 3.8 & 4.3 & 4.0 & 4.7 & 4.7 & 5.3 & 5.4 & 5.6 & 6.1 & 7.1 & 7.8 & 9.8 & 10.0 & 10.7 \\
\hline
\end{tabular}

(출처 : The Cambodia Development Effectiveness Report 2011) 
는데, 공교롭게도 이는 원조효과성에 관한 파리선언(2005년) 등 국제원조사회의 이슈와도 시기 적으로 잘 부합했던 측면이 있다.

이상의 특징을 중심으로 캄보디아와의 역사적 이해관계가 복잡하게 얽혀있는 일본, 미국, 중 국 등 소위 '빅3’ 에 해당하는 공여국의 캄보디아 원조를 구체적으로 살펴보도록 하자. 특히 상 기한 3 국은 캄보디아와 불편한 과거를 가지고 있으면서 동시에 최대 원조공여국으로 활동하고 있다는 점에서 캄보디아의 원조흐름을 현대사와 결부시켜 이해하는데 도움이 될 수 있다.

\section{(2) 일본}

일본은 가장 초창기부터 가장 많은 원조를 제공한 캄보디아 최대 원조국이다. 1992년부터 2011 년까지 총 20.8 억불을 제공하였는데, 이는 매년 평균 1 억불 수준의 원조를 꾸준히 집행해 왔다는 뜻이다. 대 캄보디아 전체 원조총액의 $17.2 \%$ 를 차지한다. 공여국 중 전체규모 2 위인 미 국이 7.8 억불(6.4\%) 수준에 불과하다는 점을 볼 때 일본의 압도적인 원조규모를 확인할 수 있다.

일본은 경제적 이해관계에 따라 $\mathrm{ODA}$ 를 실시하는 것으로 잘 알려져 있다. 그런데 그러한 $\mathrm{ODA}$ 정책기조가 캄보디아 경우에 꼭 들어맞지는 않다. 원조수행 과정만 놓고 보면 오히려 인 도주의적 전후복구에 충실했던 것으로도 해석될 수 있다. 1970-80년대 캄보디아의 정치 · 사회 적 혼란을 안정화시키기 위해 일본은 파리평화협정 이후 신속히 프랑스와 함께 원조공여국회의 를 주도함으로써 원조를 통한 사회 안정의 기틀을 닦았다. ${ }^{11)}$ 당시 피폐한 소국 캄보디아와 경제 적 이해관계가 전혀 없던 일본의 적극적인 원조개입 정책은 매우 이례적이면서도 동시에 후속 원조의 물꼬를 텄다는 점에서 그 자체로 타 공여국에 모범을 제시한 것으로 볼 수 있다. 이는 캄 보디아를 중심으로 하는 동남아시아 지역의 정치 · 경제적 안정이 일본의 평화유지와 안보에 큰 영향을 미친다는 정책적 판단의 결과이며, 동시에 식민지배 역사라는 과거로부터의 단절과 화 해의 노력으로 해석될 수 있다.

그렇다고 경제논리가 완전히 무시되었다고 볼 수는 없다. 2000년대 들어 사회가 안정기에 접 어들고 경제도 크게 성장하면서 일본은 교육과 보건, 관개시설 등 생활환경 개선을 위한 원조 중심에서 도로, 항만, 발전 등 대단위 인프라가 수반되는 원조로 우선순위를 조정하는 경향을

11) 일본은 1992년 평화유지군을 파견하여 캄보디아의 평화와 안정을 위한 노력을 구체화했다. (일본대사관, http://www.kh.emb-japan.go.jp/economic) 
보였다. 이는 자연스럽게 일본기업의 진출과 투자환경 조성에 긍정적인 메시지를 주기 위한 것 으로, 결과적으로 일본 JETRO(한국의 KOTRA에 해당하는 무역투자진흥기관)가 2010년 수도 프놈펜에 사무소를 개설하는 등 새로운 환경이 조성될 수 있었다. ${ }^{12)}$ 물론 일본이 원자재 확보나 투자시장 진출 등의 핵심 수혜자라 하기는 어렵다. 이미 캄보디아 내 중국의 영향력이 매우 크 고 선점효과도 탁월하기 때문이다. 오히려 일본은 중단 없는 $\mathrm{ODA}$ 를 통해 어려운 이웃 캄보디 아를 돕는 이미지를 확산시킴으로써 과거 대동아공영의 부정적인 역사를 캄보디아 국민들로부 터 지워나갈 수 있게 되었다는 점이 성과라 하겠다.

\section{(3) 미국}

1969년 중립주의를 표방하던 캄보디아는 베트남과의 총력전을 펼치던 미국으로부터 무차별 포탄공격을 받는다. 베트남으로 통하는 지원루트를 차단하려는 의도였으나, 결국은 대규모 인 민살상으로 이어지는 사건이었다. 이후 캄보디아 내 쿠데타가 일어나 친미 꼭두각시 정부가 들 어서면서 결정적으로 반미 · 반서방을 모토로 하는 크메르루즈가 태동하는 빌미를 제공했다. 이 런 과거사로 인해 지금도 미국은 캄보디아와의 관계가 원만하지 못한 게 사실이다.

미국의 $\mathrm{ODA}$ 도 일정 부분 미국과 캄보디아와의 관계를 반영한다. 자국의 안보전략을 고려 한 대외원조가 특징인 미국은 동남아 지역 내 평화유지와 민주주의 전파를 위해 캄보디아 원조 를 적극 활용하였다. 캄보디아에 민주정부가 구성되기 직전인 1992년 미국 원조의 대외창구인 USAID가 캄보디아에 사무소를 개설하면서 본격적인 활동이 시작되었고, UNTAC의 활동과 함 께 선거와 거버넌스 부분에 지원을 집중했다. 이는 동남아 지역 내 안정적인 민주정부 수립이라 는 당시 클린턴 정부의 개입주의 외교정책의 결과라 할 수 있다. 정부 구성이 초기단계인데다 원조 없이는 국가성장의 토대마련이 어려웠던 캄보디아로서는 미국과의 악연에도 불구하고 개 입주의적 원조를 수용할 수밖에 없었다. ${ }^{13)}$

이러한 원조의 흐름에 변화가 온 것은 2000 년대 들어서부터이다. 사회 안정을 바탕으로 한

12) 2000년대 후반 일본기업의 진출과 투자가 확대되긴 했으나 타국과 비교하면 여전히 매우 저조하다는 점이 이채 롭다. 2002년부터 2009년까지 일본의 투자액은 1억3천만불인데 비해, 중국(1위)은 67억5천만불, 한국(2위)은 26 억6천만불, $\mathrm{ASEAN}$ (3위)은 16억8천만불 등 규모면에서 크게 차이가 난다. (KOTRA, http://www.globalwindow.org)

13) 개입주의의 한 예로, 1997 년 캄보디아 집권당 내의 내분과 내전움직임 등 지역안보와 민주주의에 역행하는 상황 이 발생했을 때 미국은 당시 원조자금의 2/3를 지원 철회한 바 있다. (USAID, http://cambodia.usaid.gov) 
정부의 영향력이 증대되면서 캄보디아는 국가개발계획을 주도적으로 수립하여 그 틀에서 원조 를 수용하는 방향을 견지하기 시작했다. 미국의 정치적 원조에 대한 일종의 견제로도 결과적으 로 해석될 수 있는 부분이다. 이후 미국은 정치적 원조이슈보다는 보건과 교육분야에 집중하여 원조를 수행하게 된다. 2000년의 HIV/AIDS분야 지원협력과 2002년 초등교육 지원협력 등이 이 때 등장했다. 즉, 자기 목소리를 내기 시작한 원조 수요자와 과거사로부터 자유롭지 못한 원 조 공급자의 힘의 관계가 조금씩 역전이 되는 과정이 진행된 것이다.

$\mathrm{ODA}$ 를 둘러싼 긴장이 다소 해소된 것은 2000 년대 말부터라 볼 수 있다. 이때는 중국의 캄보 디아 원조가 본격화하고 인도차이나 반도에 대한 지정학적 가치가 높아지는 등 대외 여건이 크 게 바뀐 시기였다. 미국은 중국에 대한 견제와 역내 영향력 확대 목적으로 ODA를 크게 늘리기 시작했다. 그간 연평균 3 천만불 수준의 미국의 $\mathrm{ODA}$ 는 2006 년 처음으로 5 천만불을 넘어섰고 이후 줄곧 연평균 6 천만불 수준을 기록하고 있다. 원조내용도 사회안전망 확충과 제도개혁에 맞춰 탈정치적으로 진행되는 추세다. 14) 2007년에는 처음으로 미국평화봉사단(Peace Corps) 이 활동을 시작했고, 2010년에는 클린턴 국무장관이 방문해 양국의 우호를 다지기도 했다. 이 처럼 양국은 최근에 와서야 근대사의 악연으로부터 조금씩 벗어나 양국 관계를 정상화해 나가 고 있으며 그 중심에 미국의 증가하는 원조가 큰 역할을 하고 있다.

\section{(4) 중국}

크메르루즈 정권을 지지하면서 결과적으로 킬링필드를 방조한 데 대해 책임이 있는 중국은 국 제사회의 캄보디아 재건과정 동참이 쉽지 못했다. 특히 크메르루즈의 몰락과 파리평화협정 이 후 캄보디아의 국가재건이 시작될 무렵에도 원조공여국 일원으로 참여하지 않았다. 이러한 기 조에 변화가 온 것은 1994 년 캄보디아 정부 대표단의 중국 방문이 계기가 되었다. 이 자리에서 중국은 크메르루즈와의 관계에 거리를 두고 캄보디아 경제재건 및 신정부 지원 입장을 천명함 으로써 과거와의 단절을 꾀했다. 캄보디아로서도 이웃하고 있는 중국과 갈등하기보다는 오히려 시급한 재건지원을 받을 수 있는 길을 택했다는 점에서 상호 이해관계가 맞았던 셈이다. 이때를 기점으로 양국 관계는 다시 정상궤도에 오를 수 있었다.

물론 초창기에는 ODA 절대규모와 영향력이 저조한 수준이었다. 중국에 있어 캄보디아는 사 회주의 국가에 대한 정치외교적 필요가 큰 것도 아니고 자원개발이나 투자 등 시장경제 논리가

14) 2006년 USAID가 발간한 '캄보디아 개발전략보고서(2006-2010)' 에도 보건증진(HIV/AIDS, 전염병, 모자보건, 보건시스템), 교육확대(기초교육, 직업교육), 거버넌스(부패방지, 사법 및 인권, 지방분권) 등을 핵심분야로 선정하 고 있다. (USAID, http://cambodia.usaid.gov) 
큰 것도 아니었기 때문이다. 한마디로 중국으로서는 캄보디아가 $\mathrm{ODA}$ 를 집중할 만큼 전략적 국 가로 인식되지 못했다. 1992년부터 2000년까지 중국이 지원한 ODA는 총 5,200만불로 전체 공여국 순위 10 위에도 들지 못하는 수준이다. 비록 관계 정상화에는 성공했지만 ODA 기여를 통한 더욱 적극적인 관계개선의 노력은 부족했다고 보아야 할 것이다.

이러한 기조가 2000 년대 들어서면서 급속히 바뀌게 된다. 일본이 시장논리에 기초한 이익실 현을, 그리고 미국이 지정학적 지역안보와 중국 견제를 목적으로 $\mathrm{ODA}$ 정책을 바꾸게 되었다면 중국은 양자를 모두 아우르는 차원에서 ODA를 활용하게 된다. 이미 1990년대 말부터 캄보디 아 내 자원개발에 눈을 돌린 도전적인 중국 기업들이 속속 등장하기 시작했다. 중국은 경제적 관점에 기초해 자국기업의 현지 활동과 관련 있는 분야에 $\mathrm{ODA}$ 를 집중하거나 기업활동을 대가 로 $\mathrm{ODA}$ 를 확대했다. 댐, 도로, 발전시설 등의 시설 인프라가 그것이다. 그리고 인도차이나 역 내 패권과 영향력 강화도 중요한 고려 요소였다. 당시 ASEAN의 부상에 따른 다극화 체제가 시 작되면서 중국은 지역의 맹주로서의 입지를 다져나갈 필요가 있었는데, 그런 점에서 캄보디아 는 중국 $\mathrm{ODA}$ 의 수혜국이 될 수 있었다.

이러한 경향의 연장선상에서 중국의 ODA는 2000년대 후반에 기하급수적으로 확대되는 특징을 보이 고 있다. 전체 ODA 8.6억불 중 약 $75 \%$ 인 6.5억불이 2007년부터 5년 사이 집행되었고, 특히 2011년에는 2 억불 이상을 지원해 일본을 제치고 최초로 원조공여국 1 위 국가가 될 전망이다. 이는 정치 - 경제적 이 해관계가 첨예화할수록 $\mathrm{ODA}$ 가 확대되는 추세로 해석되는데, 이 기간 미국의 ODA도 마찬가지로 성장 추세라는 점에서 중국과 미국이 캄보디아를 두고 벌이는 ODA 경쟁구도를 엿 볼 수 있다. 물론 원조의 진정성을 떠나 양국관계를 새롭게 써내려가는 캄보디아 입장에서 중국의 대규모 원조는 지난날 크메르 루즈에 얽힌 중국과의 과거사를 정리하는 일종의 보상으로 인식될 수도 있을 것이다.

\section{5. 캄보디아 $\mathrm{ODA}$ 전망}

캄보디아는 그간 최빈국으로서는 보기 드물게 수동적 원조수혜자에서 능동적 원조수혜자로 바뀐 좋은 사례라 할 수 있다. 원조회의 초창기 공여국에서 주도하던 원조 메커니즘이 점차 공 여국과의 공동 수행 체제로 전환되었으며, 2000년대 중반부터는 형식상 캄보디아가 주도하는 모양새로 정착이 되었다. 그 과정에서 앞서 설명한 $\mathrm{CDCF}$ 개발협력포럼 외에도 정부-공여국간 연석회의(GDCC, Government-Development Partner Coordination Committee), 분과별 위원회(TWG, Technical Working Groups) 등의 원조협의 채널이 공여국과의 파트너십에 주 요한 구실을 하고 있다. 
그렇다고 해서 $\mathrm{ODA}$ 협의의 축이 캄보디아로 완전히 넘어간 것은 아니다. 원조의 효과적이고 투명한 집행, 원조환경의 우호적 개선, 새천년개발목표를 포함한 국제사회 공동과제 수행노력 등에 대해 공여국의 발언권도 여전히 크다. 정부부처 주요 자리에 정책자문 역할을 위한 공여국 파견관들이 활동하면서 정부 내에서 영향력을 행사하는가 하면, 공여그룹이 주최하는 월례회의 에서 각종 ODA 개선과제를 제기하는 등 정부 외부에서도 견제가 활발하다. 결국은 ODA 예산 을 쥐고 있는 공여국을 무시할 수 없는 현실적인 상황인데, 캄보디아 정부와 공여국은 이를 일 종의 견제와 균형의 상호작용으로 풀어간다고 할 수 있겠다.

이와 관련하여 최근 특기할 만한 일이 발생했다. 지난 2011년 8월 캄보디아 정부는 최고위급 원조회의인 $\mathrm{CDCF}$ 포럼을 2개월 앞두고 갑작스레 취소를 결정해 공여국측에 일방적으로 통보 했다. 회의의제 선정에 대한 합의가 늦어진 것이 표면적인 이유였는데, 실제로는 원조환경을 둘 러싼 양측의 힘겨루기로 해석되고 있다. 캄보디아 정부의 $\mathrm{ODA}$ 역할과 주도권이 커갈수록 상대 적으로 발언권이 위축되었던 공여국 그룹이 본격적으로 정부의 수원 행태를 비판하면서 문제가 촉발되었다는 시각이다.

여기에는 몇 가지 배경이 있다. World Bank이 지원하던 토지구획정비사업이 원거주지를 빼 앗긴 이주민들과의 갈등으로 인해 사업이 중단된 사례, 정부에서 진행하던 프놈펜 도심지정비 사업에서 반인권적 이주민 문제가 야기됨에 따라 World Bank가 차관공여를 동결한 사례, 정 부에서 입법중인 $\mathrm{NGO}$ 법이 공여국의 반대로 계류된 사례 등 최근 $\mathrm{ODA}$ 를 둘러싼 양자 간 갈등 국면이 계속되고 있는 것이다. 원조자금 동결과 같은 위협적인 결정이 공공연하게 언급되는 한 갈등은 쉽게 봉합되지 못할 것이라는 우려의 목소리도 높다. 이런 배경에서 $\mathrm{CDCF}$ 포럼도 캄보 디아 정부에서 일방적으로 취소한 게 아니냐는 분석이다.

그럼에도 불구하고 캄보디아 ODA 전망이 비관적이지만은 않다. 여전히 최빈국이라는 대의명 분이 있고 원조정책이나 효과성도 상당히 개선되어 왔기 때문에 국제사회의 ODA가 크게 위축 되지는 않을 것으로 전망된다. 세계적인 금융위기의 여파 속에서도 캄보디아에 대한 ODA는 꾸 준히 늘었으며 2011년에는 역대 최고인 12 억불 규모의 원조가 예상된다. 앞서 본 '빅3 공여국' 의 정치 · 경제적 이해관계가 첨예화하는 상황도 $\mathrm{ODA}$ 확대에 긍정적으로 작용할 것이다. 여전 히 국제사회의 원조 없이는 국가운영에 어려움이 큰 캄보디아 정부로서도 공여국과 갈등만을 노출시키는 것은 바람직하지 못한 게 현실이다. 수원국과의 $\mathrm{ODA}$ 파트너십을 강조하는 공여국 입장에서도 무원칙적인 $\mathrm{ODA}$ 정책을 펼 수는 없을 것이다. 현대사의 굴곡을 경험하며 마침내 성장의 플랫폼에 올라 선 캄보디아 정부가 앞으로 어떻게 공여국과의 관계를 조율해 나갈 것인 지 귀추가 주목된다. 


\section{6. 결론: 수원국 ODA 연구의 새로운 접근방법 모색}

$\mathrm{ODA}$ 연구에 대한 학문적 관심에서 수원국의 현대사는 그간 특별한 주목을 받지 못한 게 사 실이다. 금번 글을 준비하는 과정에서도 '현대사를 통해 본 수원국의 ODA' 자료는 취득이 매 우 제한적이었다. 수원국의 시기별 원조흐름 정도를 개괄적으로 설명하는 내용은 확인이 가능 하나 공여국이 현대사와 어떤 관련이 있고 그것이 어떻게 $\mathrm{ODA}$ 에 어떻게 영향을 주었는지에 대 한 별도의 분석은 확인이 어려웠다.

이는 아마도 원조를 현대사 분석의 틀 안에서 다루는데 관심이 부족했던 때문으로 판단되는 데, $\mathrm{KOICA}$ 를 포함한 국내의 원조 담론이 성과관리와 집행의 효율화 혹은 국제사회의 규범준수 등 당면과제 중심으로 흐르다 보니 인문학적 고려가 상대적으로 소외되지 않았나 생각된다. 역 사뿐만 아니라 수원국의 문화와 전통, 수원국민들의 심리와 심성, 지역커뮤니티와 시민사회 등 $\mathrm{ODA}$ 를 통해 상관관계를 분석할 수 있는 소재가 무궁무진하다는 점에서 새로운 분야 연구에 대 한 관심이 요청된다. 15$)$

특히 역사는 정치·경제적 변화와 사회·문화적 현상을 동시에 들여다볼 수 있는 창(空)이라 할 수 있다. 역사라는 창을 통해 ODA를 조망할 때 숫자와 통계라는 컨텐츠 뒤편에 숨어 있는 정황과 문맥의 컨텍스트를 찾아내게 된다. 그때야 비로소 수원국에 대한 더 깊은 이해와 인식을 바탕으로 우리가 꿈꾸는 진정한 개발파트너십을 마련해 나갈 수 있다. 과거와 현재를 아는 것이 미래를 전망하는 출발점이라는 것은 개발원조에도 동일하게 적용된다. $\mathrm{ODA}$ 연구의 새로운 접 근방법으로서의 수원국 현대사 공부는 그런 점에서 $\mathrm{KOICA}$ 를 포함한 국제협력사업 수행기관에 반드시 필요한 선행학습이라 하겠다. 향후 이에 대한 폭넓은 논의와 연구가 있기를 기대한다.

15) 이러한 작업은 수원국으로서의 한국 ODA에 대해서도 동일하게 적용될 수 있다. 한국의 수원역사 연구는 평면적 인 연대기적 흐름을 경제성장과 연결하는 수준에서 개괄하고 있다. 그렇다 보니 ODA와 우리 현대사의 다층적 상관관계에 대한 분석이 미흡할 수밖에 없었다. 일례로, 일본이 한국에 제공한 원조는 약 50 억불인데, 이중에는 대일청구권 자금협상과 한일국교 정상화 조치 등의 협상 결과로 받은 식민지배 보상금도 포함되어 있다. 보상금 으로 지급된 원조가 우리 사회 내 일본에 대한 감정과 인식을 어떻게 바꿔왔는지에 대한 고민도 사회사적으로 좋 은 사례라 할 수 있다. 일제 강제징용 피해보상과 위안부에 대한 보상 등은 여전히 현재진행형의 국민 관심사이 기 때문이다. 


\section{참고문헌}

\section{1. 국내문헌}

손혁상 외, 2010, 〈대캄보디아 ODA 정책 수립을 위한 기초조사 및 전략개발 연구〉, 대외경제 정책연구원

유재원 외, 2010, 〈ASEAN 후발 3개국의 사회경제 개발역량 제고에 관한 기초연구〉, 대외경제 정책연구원

박복영, 2007, 〈원조모형의 국제비교와 시사점〉, 대외경제정책연구원

외교통상부, 2009, 〈캄보디아 개황〉

한국국제협력단, 2011, 〈캄보디아 협력전략 2012-2015〉(초안)

\section{2. 국외문헌}

Council for the Development of Cambodia, 2009, 〈National Strategic Development Plan 2009-2013>

Council for the Development of Cambodia, 2011, 〈The Cambodia Development Effectiveness Report 2011>

JICA, 2002, 〈The Kingdom of Cambodia〉

JICA, 2010, 〈Diversity and Transformation of Aid Patterns in Asia's "Emerging Donors"> 